\title{
Psychiatry under National Socialism: Remembrance and Responsibility
}

\author{
Frank Schneider
}

Published online: 30 September 2011

(C) Springer-Verlag 2011

\section{Ladies and Gentlemen!}

Under National Socialism, psychiatrists showed contempt towards the patients in their care; they lied to them and deceived them and their families. They forced them to be sterilised, arranged their deaths and even performed killings themselves. Patients were used as test subjects for unjustifiable research—research that left them traumatised or even dead.

Why has it taken us so long to face up to these facts and deal openly with this dark chapter in our history? Although we are proud that the German Association for Psychiatry and Psychotherapy (DGPPN) is one of the oldest scientific medical associations in the world, for too long now we have been hiding, denying a crucial part of our past. For that, we are truly ashamed.

It is also a disgrace that we, the DGPPN, did not even stand up for the victims in the period after 1945. Worse still, we were partially responsible for the renewed

\footnotetext{
The original German text of this speech of the president of the German Association for Psychiatry and Psychotherapy (DGPPN) at the annual convention of the DGPPN from 26 November 2011 was unanimously adopted by the Executive Board of the DGPPN as an Association Document on 23 November 2010. We are very grateful to Carsten Burfeind, MA (Berlin), and Prof. Dr. Volker Roelcke (Gießen) for their comments and suggestions. The German version was first published as: Schneider F (2011) Psychiatrie im Nationalsozialismus-Erinnerung und Verantwortung. Nervenarzt 82:104-120. An extended documentation of the memorial event was published as: Schneider F (2011). Psychiatry under National Socialism. Psychiatrie im Nationalsozialismus. Springer, Berlin.
}

F. Schneider $(\bowtie)$

Klinik für Psychiatrie, Psychotherapie und Psychosomatik, Universitätsklinikum Aachen, Pauwelsstr. 30,

52074 Aachen, Germany

e-mail: fschneider@ukaachen.de discrimination that they faced in the post-war period. We are at a loss to explain why we are only now in a position to hold an event such as this.

I stand before you today as President of an association that has taken nearly 70 years to end this silence and recall the tradition of enlightenment through science in which it stands. An independent scientific commission is currently overseeing a research project that is addressing the history of the association, or rather its predecessors, in the period between 1933 and 1945.

But this is not enough. Irrespective of any research results, which we expect to receive in the next few years, I must offer our sincerest apologies-albeit shamefully late- to all the victims and their families who suffered such injustice and pain at the hands of the German associations and their psychiatrists.

The German Association for Psychiatry and Psychotherapy has decided to give a clear signal by holding this commemorative event as a way of acknowledging and of standing up for the victims, of coming to terms with our past and of learning from this bleak period in our history.

Ladies and gentlemen, welcome to this commemorative event. It is wonderful to see so many of you here and I would like to take this opportunity to thank you all for coming.

The letters and documents we have just heard at the beginning of this commemorative event provide moving testimonials of the pain and suffering that mentally ill people were subjected to.

Psychiatry under National Socialism is one of the darkest chapters in the history of our discipline. Throughout this period, psychiatrists and representatives of psychiatric associations repeatedly disregarded and heinously reinterpreted their professional duty to treat and care for their patients. 
Psychiatry was corruptible and it corrupted, it cured and it killed. It no longer felt it had an obligation to individuals; rather, in the name of supposed progress-the liberation of an entire society from the burden of providing welfare, improvements in the genetic make-up of an entire nation and, ultimately, humanity's "deliverance from misery"1psychiatrists abused and killed vast numbers of people. They also saw to it that any undesirable colleagues were forced out of their jobs.

It is important to remember that between 1933 and 1945 many of the psychiatrists working in academia emigrated from the Reich. ${ }^{2}$ They did not leave voluntarily. Psychiatrists of Jewish descent or those who had the wrong political views were forced out of their jobs and had to stop practicing. They and their families lost their livelihoods, their belongings and all too often their home country. Driven out of Germany, they had to create new lives for themselves as strangers in an unfamiliar, foreign land.

Most of those who could not flee Germany or Austria were deported to concentration or extermination camps. Few survived, and nothing we do can ever make up for the fate they suffered.

This was all happening at a time when psychiatric research in the Reich was becoming increasingly focused on eugenics and "racial hygiene." 3 National Socialist healthcare, social and economic policies favoured those who would most benefit the nation's health and productivity. The weak were to be eliminated so that the strong could become even stronger. This devastating approach was nothing new.

The term "eugenics" had been in use since the late nineteenth century, ${ }^{4}$ and the practice of sterilising mentally

\footnotetext{
1 Title of a book by E. Mann published in 1922 by Fritz Fink Verlag, Weimar.

2 Outlined in Zalashik R, Davidovitch N (2009) Professional identity across the borders: Refugee psychiatrists in Palestine, 1933-1945. Social History of Medicine 22:569-587; Weindling P (2010) Alien Psychiatrists: The British assimilation of psychiatric refugees. In: Roelcke V, Weindling P, Westwood L (eds) International Relations in Psychiatry: Britain, America, and Germany to World War II. University of Rochester Press, Rochester/NY, pp 218-235.

${ }^{3}$ Roelcke V, Hohendorf G, Rotzoll M (2000) Psychiatric science, 'Euthansia' and the 'new man': The debate on anthropological premises and values in national socialist medicine ("Psychiatrische Wissenschaft, 'Euthanasie' und der 'Neue Mensch': Zur Diskussion um anthropologische Prämissen und Wertsetzungen in der Medizin im Nationalsozialismus)." In: Frewer A, Eickhoff C (eds) "Euthanasia" and the current debate on assisted suicide. The historical background of medical ethics ["Euthanasie" und die aktuelle Sterbehilfe-Debatte. Die historischen Hintergründe medizinischer Ethik], Campus, Frankfurt/M., pp 193-217.

${ }^{4}$ Weingart P, Kroll J, Bayertz K (1988) Race, blood and genes (Rasse, Blut und Gene), Suhrkamp, Frankfurt/M., p 284; Nowak K (1980) Euthanasia and sterilisations in the "Third Reich" ("Euthanasie" und Sterilisierungen im "Dritten Reich"). Vandenhoeck \& Ruprecht, Göttingen, p 39.
}

ill patients was being promoted in the Scandinavian and Anglo-Saxon countries as well as in the German Empire. In the summer of 1914, a proposed Bill on Sterilisation and Abortion was put forward in the Reichstag. It was only the outbreak of war that stopped the Bill passing into law. ${ }^{5}$

On 14 July 1933, not long after Hitler seized power, the NSDAP passed a Law for the Prevention of Hereditarily Diseased Offspring. The psychiatrist Ernst Rüdin, who was President of the psychiatric association from 1935 to 1945 , was involved in writing the official commentary ${ }^{6}$ to the law when he was director of the German Research Institute for Psychiatry. ${ }^{7}$ The law described sterilisation-forced sterilisation-as "protecting future generations." 8 This is a truly perverse view that offsets one person's pain and suffering against another's well-being.

The law classed manic-depressive illness and schizophrenia as genetic mental illnesses. The same applied to many other conditions, such as hereditary forms of epilepsy, blindness, deafness, dwarfism, etc. The idea was to stop sick people having children so that their supposedly bad genetic material did not continue to pollute the health of the "Volk."

All doctors were obliged to report "hereditarily diseased" individuals to the authorities. Under the law, doctors forcibly sterilised more than 360,000 people. Over 6,000 died as a consequence of the operations.

Since the concepts of eugenics and racial hygiene were so popular at the time, many psychiatrists held the sterilisation law in high regard. As President of our predecessor organisation, the Society of German Neurologists and Psychiatrists (GDNP), Ernst Rüdin spoke in its favour several times at the openings of annual congresses. ${ }^{9}$ Other countries around the world also supported eugenics-based sterilisation. However, what set Germany apart was the fact that its law allowed people to be sterilised against their

\footnotetext{
${ }^{5}$ Ganssmüller C (1987) The Third Reich's sterilisation law policy (Die Erbgesundheitspolitik des Dritten Reiches). Böhlau, Cologne, p $13 \mathrm{f}$.

${ }^{6}$ Gütt A, Rüdin R, Ruttke F (1936) Law for the prevention of heriditarily diseased offspring of 14 June 1933, with implementing ordinances (Gesetz zur Verhütung erbkranken Nachwuchses vom 14. Juni 1933 nebst Ausführungsverordnungen). J.F. Lehmanns, Munich, 2nd edition.

${ }^{7}$ Roelcke V (2008) Science in the service of the Reich: Ernst Rüdin and the German Institute for Psychiatric Research (Wissenschaft im Dienst des Reiches: Ernst Rüdin und die Deutsche Forschungsanstalt für Psychiatrie). In: Hockerts G, Hajak S (eds) Munich and national socialism (München und der Nationalsozialismus). Metropol, Berlin, pp 313-331.

8 loc. cit., p 5, in the preface to the first edition of 1934 (note 6).

9 Rüdin E (1939) The importance of research and cooperation of neurologists and psychiatrists in the national socialist state (Bedeutung der Forschung und Mitarbeit von Neurologen und Psychiatern im nationalsozialistischen Staat). Zeitschrift für die gesamte Neurologie und Psychiatrie 165:7-17.
} 
will. For its victims, the legislation was an appalling attack on the very core of their identity - an attack they were powerless to stop and that permanently robbed them of their right to physical integrity and to parenthood.

Even once the war had ended, shame and silence continued to shroud what the victims and their families had endured. To this day, the Federal Republic of Germany has still not formally recognised these individuals as victims of Nazi persecution, despite the fact that the sterilisation law was an unequivocal expression of National Socialist, German racial ideology. The commentary to the law makes this very clear:

"What is the aim of measures for the genetic and racial hygiene adequate for the German Volk? The existence at all times of a sufficient number of genetically healthy large families that are racially valuable to the German people." 10

At this point, I would like to express my admiration for Dorothea Buck. The sculptor and author, who was herself one of the victims, co-founded the "Federal Organisation of (Ex-)Users of Psychiatry" in Germany. She has tirelessly dedicated herself to raising awareness of the issues and to ensuring that they are not forgotten. Klara Nowak, who passed away years ago, was another such person. Ms Nowak's 1987 initiative resulted in the creation of the 'Federation of Those Affected by 'Euthanasia' and Forced Sterilisation" which since then fought for the social rehabilitation of victims.

Yet the violence did not end at forced sterilisationpeople were also murdered. In the 1920s, as a result of the World War and the Great Depression, disabled people began to be seen as financial burdens. Psychiatrist Alfred Erich Hoche published Allowing the Destruction of Life Unworthy of Living in 1920 in collaboration with the lawyer Karl Binding. In it, he coined the term "human ballast" and drew up a list of allegedly incurable mental illnesses that rendered sufferers "mentally dead." 11 This provided the basis for the call for "death to life unworthy of life!" published in 1930 in the National Socialist monthly bulletin. ${ }^{12}$

\footnotetext{
${ }^{10}$ It continues: "However, this goal can only be achieved and ensured over the long term if the concept of breeding remains at the core of our concept of racial hygiene. The future keepers of the law must bear in mind the aim of ensuring the bloodstock of the German people [...] remains pure." loc. cit., p 55 (note 6).

${ }^{11}$ Binding K, Hoche A (1920) Allowing the destruction of life unworthy of living. To what extent and in what form (Die Freigabe der Vernichtung lebensunwerten Lebens. Ihr Maß und ihre Form). Meiner, Leipzig, 1920 (2nd edition 1922), p 57, cited in Nowak K, loc. cit., p 51 (note 4).

12 Nationalsozialistische Monatshefte 1, 1930, p 298, cited in Nowak K, loc. cit. p 43.
}

Later, Hitler issued a decree to start a "euthanasia" programme. It was backdated to 1 September 1939, the date that Germany invaded Poland and World War II began. Professor Werner Heyde, chair of psychiatry and neurology of Würzburg University, was appointed Medical Director of the programme that would later become known as "Aktion T4." It is thought that, by the end of the warand even several weeks afterwards-Aktion T4 and the killings that took place once the programme had officially ended claimed the lives of at least 250,000-300,000 mentally and physically disabled people. ${ }^{13}$

From October 1939, all psychiatric hospitals and associated areas in the Reich received registration forms from Columbushaus on Potsdamer Platz, and as of April 1940 from Tiergartenstraße 4, where the Berlin Philharmonic stands today. The forms were used to systematically record all patients and select who should die. Decisions were mainly based on "usefulness" criteria, that is, on how much work a person was capable of. ${ }^{14}$

Today, at the site of the former central administration office for the killings, all that commemorates the "euthanasia" victims is an indistinct plaque in the ground and a sculpture that was only dedicated to them upon completion. There is still no central, national memorial to the victims. This is a clear expression of the continuing denial surrounding the events and of the humiliation that the survivors and their families still endure. It also represents a blind spot in the collective memory of our country and of German psychiatry. We at the DGPPN will be supporting current efforts to establish an appropriate national $\mathrm{T} 4$ commemorative and information centre.

Approximately fifty selected assessors, some of them renowned psychiatrists, evaluated the registration forms they received from the hospitals and decided who would live and who would die. Among the assessors were Werner Villinger, Friedrich Mauz and Friedrich Panse, all of whom held the office of President in our association during the post-war period. ${ }^{15}$ Friedrich Mauz and Friedrich Panse also later became honorary members. Although membership

\footnotetext{
$\overline{13}$ Faulstich $\mathrm{H}$ (2000) The number of 'Euthanasia' victims (Die Zahl der 'Euthanasie'-Opfer). In: Frewer A, Eickhoff C (eds) "Euthansia" and the current debate on assisted suicide. The historical background to medical ethics (Euthanasie und die aktuelle Sterbehilfe-Debatte. Die historischen Hintergründe medizinischer Ethik). Campus, Frankfurt/M., pp 218-234.

${ }^{14}$ Rotzoll M, Hohendorf G, Fuchs P et al. (2010) The national socialist "Euthanasia" campaign "Aktion T4" and its victims (Die nationalsozialistische "Euthanasie"-Aktion "T4" und ihre Opfer). Schöningh, Paderborn.

15 Schmuhl H-W (1987) Racial hygiene, national socialism, euthanasia: from contraception to the destruction of "life unworthy of living" 1890-1945 (Rassenhygiene, Nationalsozialismus, Euthanasie: Von der Verhütung zur Vernichtung "lebensunwerten Lebens" 1890-1945). Vandenhoeck \& Ruprecht, Göttingen, p 192.
} 
ends with the death of the individual, we condemn both these cases and will formally revoke the honours.

Patients selected for death would be collected from their hospitals in grey buses that have now come to symbolise the killings, and taken to one of six mental institutions equipped with gas chambers. Medical facilities thus became extermination centres. Healing became destruction. Psychiatrists watched as the patients entrusted to their care were taken away to be murdered. In the order they were established, the six institutions were as follows: Grafeneck, Brandenburg, Hartheim, Pirna-Sonnenstein, Bernburg and Hadamar.

"Aktion T4" lasted nearly 2 years, from January 1940 to August 1941. Within that time, over 70,000 patients were killed. The public protests that eventually spelled the demise of the programme did not come from the ranks of the psychiatric profession, but predominantly from the Church. The crucial sermon against the killing programme was delivered on 3 August 1941 by Clemens August Graf von Galen, Bishop of Munster and Cardinal of the Roman Catholic Church. "Aktion T4" was officially stopped immediately afterwards. ${ }^{16}$

But the Nazis took the knowledge and experience gathered during "Aktion T4" and applied them to the concentration camps to murder even more people-this time in their millions. ${ }^{17}$

At the same time as they were implementing Aktion T4, the Nazis were also murdering physically and mentally disabled children in over 30 psychiatric and paediatric hospitals as part of what is usually called "child euthanasia." Previously, it was thought that approximately 5,000 children had died. This figure was given by the perpetrators during post-war trials and then generally accepted as true. We now know that the actual number was far greater.

And yet the killing continued, even after the centrally organised "Aktion T4" was officially stopped. During this decentralised phase of "euthanasia," doctors in psychiatric facilities seeking to free up beds and save money killed patients — possibly many 10,000 — by administering overdoses or providing them with so little food that they starved to death. ${ }^{18}$ In a report on new admissions in 1943, Gerhard

\footnotetext{
${ }^{16}$ Cf. Schmuhl, Racial hygiene (Rassenhygiene), pp 210-214.

${ }^{17}$ Friedlander $H$ (1995) The origins of Nazi genocide: from euthanasia to the final solution. University of North Carolina Press, Chapel Hill.

18 Outlined in Faulstich H (1998) Starvation in psychiatry 1914-1949. With a topography of Nazi psychiatry (Hungersterben in der Psychiatrie 1914-1949. Mit einer Topographie der NSPsychiatrie). Lambertus, Freiburg/Br.; for a local example, cf. Schwarz P (2002) Murder by starvation, 'wild Euthanasia', and 'Aktion Brandt' at Steinhof during national socialism (Mord durch Hunger. Wilde 'Euthanasie' und 'Aktion Brandt' am Steinhof in der NS-Zeit). In: Gabriel E, Neugebauer W (eds) From forced sterilisation to murder (Von der Zwangssterilisierung zur Ermordung). Böhlau, Vienna, pp 113-142.
}

Wischer, director of the Waldheim psychiatric hospital, put it very succinctly:

"Of course I could never accommodate the new patients without undertaking certain measures to free up space. The process itself is very straightforward, but there is a distinct shortage of the necessary medication." 19

Today, it is hard to imagine that psychiatrists allowed patients in their care to be killed that they chose who should live or die and then medically, scientifically-well, pseudo-scientifically-oversaw the deaths of children, adults and elderly people.

An entry in a medical file from 1939 on a female patient suffering from a schizophrenic disorder, which is archived at the Federal Archives here in Berlin, reads as follows:

"As before. Mentally dead. No change can be expected, so medical record should be closed. The only entry worth making is the date of death." 20

Before they were murdered, many patients were used for "research." This involved ethically unjustifiable experiments that are far removed from scientific and research values. One example is the "euthanasia"-related experiments on mentally ill children and teenagers by Carl Schneider, Chair and Professor of Psychiatry at Heidelberg University, in collaboration with Julius Deussen, an employee at the German Research Institute for Psychiatry in Munich. The research involved elaborate experiments on patients, followed by their killing and autopsies. ${ }^{21}$ Patients at psychiatric hospitals were also used as test subjects in

\footnotetext{
${ }^{19}$ Letter of 4 Nov. 1943 from Dr. Wischer to Professor Nitsche, head of Central Department I, cited in Schmuhl, Racial hygiene (Rassenhygiene), 1992, p 232 (cf. Aly G (1985) Medicine against the useless (Medizin gegen Unbrauchbare). Beiträge zur Nationalsozialistischen Gesundheits-und Sozialpolitik 1:9-74, specifically p 61); cf. also Klee E (1983) "Euthanasia" in the Nazi state ("Euthanasie" im NS-Staat). S. Fischer, Frankfurt/M., p 427.

${ }^{20}$ Federal Archives Berlin R 179/24884, cited in Rotzoll M, Fuchs P, Richter P, Hohendorf G (2010) The national socialist 'Euthanasia' campaign 'Aktion T4' (Die nationalsozialistische 'Euthanasieaktion T4'). Nervenarzt 81:1326-1332, specifically p 1331.

${ }^{21}$ Roelcke V (2000) Psychiatric science in the context of national socialist policy and 'Euthanasia': The role of Ernst Rüdin and the German Institute for Psychiatric Research (Psychiatrische Wissenschaft im Kontext nationalsozialistischer Politik und 'Euthanasie': Zur Rolle von Ernst Rüdin und der Deutschen Forschungsanstalt für Psychiatrie). In: Kaufmann D (ed) The Kaiser Wilhelm Society under national socialism [Die Kaiser-Wilhelm-Gesellschaft im Nationalsozialismus]. Wallstein, Göttingen, pp 112-150; Roelcke V, Hohendorf G, Rotzoll M (1998) Research into hereditary psychology in the context of 'Euthanasia': new documents and perspectives on Carl Schneider, Julius Deussen and Ernst Rüdin (Erbpsychologische Forschung im Kontext der 'Euthanasie': Neue Dokumente und Aspekte zu Carl Schneider, Julius Deussen und Ernst Rüdin). Fortschritte der Neurologie und Psychiatrie 66:331-336.
} 
TB vaccination trials in Kaufbeuren, ${ }^{22}$ in work on the viral aetiology of multiple sclerosis in Werneck $^{23}$ and in neuropathological examinations on "euthanasia" victims who had probably been selected especially for this purpose. This was the project Julius Hallervorden carried out at the Kaiser Wilhelm Institute for Brain Research in BerlinBuch in collaboration with the Brandenburg-Görden asylum, which was run by psychiatrist Hans Heinze. ${ }^{24}$

The murdered patients' bodies and individual histopathological specimens were in high demand among scientists, and the research findings gained were being published even after the war ended. The Kaiser Wilhelm Institute for Brain Research used the brains of at least 295 "euthanasia" victims in its work, ${ }^{25}$ and even until recently, there have been almost no qualms about using specimens taken from patients murdered during the Third Reich. ${ }^{26}$

The research was not confined to mental institutions. Tübingen-based psychiatrist Robert Ritter, for example, did research on Sinti and Roma people. He mainly focused on genealogical and epidemiological studies, which contributed to developing identification and selection criteria for "Gypsies," who would then be deported to the "Gypsy camp" at Auschwitz. ${ }^{27}$

\footnotetext{
22 Dahl M (2002) “...whom keeping alive would not benefit the nation" ("deren Lebenserhaltung für die Nation keinen Vorteil bedeutet"). In: Disabled children as test subjects and the development of the tuberculosis vaccination (Behinderte Kinder als Versuchsobjekte und die Entwicklung der Tuberkulose-Schutzimpfung). Medizinhistorisches Journal 37:57-90; cf. also von Cranach M, Siemen L (1999) Psychiatry under national socialism: Bavarian psychiatric hospitals and psychiatric asylums between 1933 and 1945 (Psychiatrie im Nationalsozialismus: Die Bayerischen Heil- und Pflegeanstalten zwischen 1933 und 1945). Oldenbourg, Munich.

23 Peiffer J (1998) Neurology in the 'Third Reich' (Neurologie im 'Dritten Reich'). Nervenarzt 69:728-733.

24 Shevell MI, Peiffer J (2001) Julius Hallervorden's wartime activities. Implications for science under dictatorship. Pediatric Neurology 25:162-165.

25 Peiffer J (2000) Neuropathology research on 'Euthanasia' victims in two Kaiser Wilhelm Institutes (Neuropathologische Forschung an 'Euthanasie'-Opfern in zwei Kaiser-Wilhelm-Instituten). In: Kaufmann D (ed) The Kaiser Wilhelm Society under national socialism (Die Kaiser-Wilhelm-Gesellschaft im Nationalsozialismus). Wallstein, Göttingen, pp 151-173.

${ }^{26}$ Peiffer J (1997) Brain research in the shadows: examples of corruptible science during national socialism (Hirnforschung im Zwielicht: Beispiele verführbarer Wissenschaft aus der Zeit des Nationalsozialismus). Matthiesen, Husum; Reports of the commission to inspect the specimen collections in the medical facilities at the University of Tübingen with regard to the victims of national socialism (Berichte der Kommission zur Überprüfung der Präparatesammlungen in den medizinischen Einrichtungen der Universität Tübingen im Hinblick auf Opfer des Nationalsozialismus), issued by the president of the University of Tübingen, Tübingen, 1990; Seidelman W (2010) Academic medicine during the Nazi period: The implications of creating awareness of professional responsibility today. In: Rubenfeld $\mathrm{S}$ (ed) Medicine after the Holocaust. Palgrave, New York, pp 29-36.
}

Granted, resistance and attempts to sabotage, the many wrongs committed in the field of psychiatry during the Nazi era did exist. Even if over $50 \%$ of physicians were members of a National Socialist organisation, i.e. the party itself or the SA or SS, which means that almost half of all doctors were not. So, doctors did have some room for manoeuvre that they could take advantage of without sanctions being imposed, and resistance did not necessarily have negative personal consequences. ${ }^{28}$

Indeed, some did resist, although they were too few in number, all too few. Among doctors with private practices, in particular, there were some who did not report a single case of possible hereditary disease to the public health authorities between 1934 and $1939 .{ }^{29}$ One reason for this might have been that doctors working outside large hospitals had much more direct contact with their patients. This fact should serve as a reminder to us not to lose sight of the patients we care for, despite the demands and pressures of our everyday work. We must never allow our professional practice to be guided by ideology, but only by the well-being of our patients.

Human dignity is always the dignity of the individual human being. No law may ever be allowed to disregard this. In 1946, Gustav Radbruch described the conflict between law and justice. In principle, the law takes precedence over justice "unless the extent to which a positive law contradicts justice is so intolerable that it must yield to justice as 'wrongful law'. [...] When justice is not even aspired to and when equality, the very essence of justice, is deliberately flouted when drafting a positive law, such law is not only 'wrongful', it is completely devoid of legality.",30

After the war ended, much the same occurred in the field of psychiatry as in many other areas of German societycollective denial. Neither psychiatric societies nor individual psychiatrists - with very few exceptions, such as Gerhard Schmidt and Werner Leibbrand-owned up to

\footnotetext{
${ }^{27}$ Zimmermann M (2007) From education to extermination: policy towards and research on gypsies in twentieth century Europe (Zwischen Erziehung und Vernichtung: Zigeunerpolitik und Zigeunerforschung im Europa des 20. Jahrhunderts). F. Steiner, Stuttgart, specifically the contributions by A. Cottebrune, M. Luchterhandt and E. Rosenhaft.

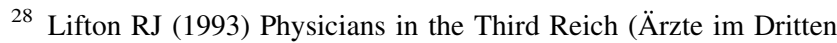
Reich). Klett-Cotta, Stuttgart, p 93ff; Klee E, p 223 ff; Roelcke V (2010) Medicine during the Nazi period: Historical facts and some implications for teaching medical ethics and professionalism. In: Rubenfeld S (ed) Medicine after the Holocaust. Palgrave, New York, pp 17-28.

${ }^{29}$ Ley A (2004) Forced sterilisation and the medical community: the background to and objectives of physicians' actions (Zwangssterilisation und Ärzteschaft: Hintergründe und Ziele ärztlichen Handelns). Campus, Frankfurt/M., pp 230-303.

${ }^{30}$ Radbruch G (1946) Legal injustice and justice beyond the law (Gesetzliches Unrecht und übergesetzliches Recht). Süddeutsche Juristenzeitung 1:105-108, specifically p 107.
} 
what had happened. This is a fact that leaves us utterly incredulous and deeply ashamed today.

The story of Professor Werner Heyde, who has already been mentioned, is particularly mindboggling. ${ }^{31}$ Heyde was the medical director of the "T4 program," and an arrest warrant was issued for him after the war. And yet from 1950 to 1959 , he enjoyed a second career as a courtappointed medical expert in Schleswig-Holstein. Although he went by the name of Dr. Fritz Sawade, there were those in the medical and legal professions who were aware of his real identity yet did not expose him. And many others, both within our field and beyond, knew about it.

At the same time, early attempts to shed light on the wrongs committed by physicians during the Nazi era were impeded and thwarted. When Alexander Mitscherlich and Fred Mielke released their book Das Diktat der Menschenverachtung [The Dictate of Contempt for Human Life], ${ }^{32}$ which documented the trials of medical doctors in Nuremberg in 1947, many doctors protested because they were worried that the reputation of their profession would be tarnished. When the duo's second book Wissenschaft ohne Menschlichkeit ${ }^{33}$ (Science without Humanity) was published in 1949, it was ignored.

Professor Gerhard Schmidt, the former director of the psychiatric clinic in Lübeck, gave a radio talk about the crimes committed against the mentally ill and the mentally disabled as early as 20 November 1945 - yet he was unable to find a publisher for his book manuscript on the topic for 20 years, despite numerous attempts. ${ }^{34}$ I read the book many years ago, and it had a profound impact on me. But many psychiatrists in post-war Germany were afraid that publicising the details of these crimes would endanger efforts to rebuild their profession and damage its reputation, which they saw still positive at the time. A grievously misguided view for the scientific community thus failed to acknowledge its responsibility. The German Psychiatric Association honoured Professor Schmidt for his life's work by presenting him with its Wilhelm Griesinger Medal in 1986, the first year it was awarded. One of our organisation's prouder moments, even if it came far too late and has sadly been almost forgotten.

\footnotetext{
31 Cf. Godau-Schüttke K-D (2010) The Heyde/Sawade affair (Die Heyde/Sawade-Affäre), 3rd edition. Nomos, Baden-Baden.

32 Mitscherlich A, Mielke F (1947) The dictate of contempt for human life: a documentation (Das Diktat der Menschenverachtung: eine Dokumentation). Lambert Schneider, Heidelberg.

${ }^{33}$ First published under the title "Science without humanity" (Wissenschaft ohne Menschlichkeit). Lambert Schneider, Heidelberg, 1949; from 1960 on under the title "Medicine without humanity: documents on the Nuremberg doctors' trials" (Medizin ohne Menschlichkeit: Dokumente des Nürnberger Ärzteprozesses). S. FischerVerlag, Frankfurt/M., 16th edition, 2004.

${ }^{34}$ Schmidt G (1965) Selection in the psychiatric hospital 1939-1945 (Selektion in der Heilanstalt 1939-1945). Evangelisches Verlagswerk, Stuttgart.
}

And what about official legislation? The German federal government enacted the Bundesgesetz zur Entschädigung für Opfer der nationalsozialistischen Verfolgung or BEG (Federal Indemnification Law) in 1956, which provided for the indemnification of victims of Nazi persecution and came into force with retroactive effect. After some revisions, the BEG-Schlussgesetz. (BEG-Final Law) was passed in 1965. Thus, all victims who had suffered persecution under the Nazi regime due to their race, religion or political views could file a claim for indemnification by 1969. However, the law did not apply to those who had been forcibly sterilised or to the families of victims of the "euthanasia," since-it was argued-they had not been persecuted due to their race ${ }^{35}$ - a further humiliation of the victims-and still we did not speak out.

Some of the expert witnesses called on during the hearings of the West German Bundestag's Restitution Committee in the 1960s were the same psychiatrists who had justified forced sterilisations and participated in systematic murder during the Third Reich. Records of 13 April 1961 report that Werner Villinger rejected the idea of compensation payments on the contemptuous grounds that the payments might cause victims of forced sterilisation to develop "neurotic ailments and suffering that could damage not only their current well-being and [...] their ability to enjoy life, but also their ability to perform." ${ }^{36}$

The Law for the Prevention of Hereditarily Diseased Offspring was not suspended until 1974. Formally, though, it continued to exist. In 1988, the West German Bundestag concluded that the forced sterilisations carried out under the Law counted as Nazi injustices. Ten years later, the Bundestag passed a law repealing the rulings of the genetic health courts. Yet it took the Bundestag until 2007 to finally ban the Law for the Prevention of Hereditarily Diseased Offspring. ${ }^{37}$ The reason given was that the Law contravened the Basic Law anyway, so was effectively

\footnotetext{
35 Cf. written report of the Restitution Committee, Bundestag printed paper 2382, pp 12f and p 57; for a good overview on this and the following cf. Surmann R (2005) What is typical Nazi injustice? The denial of compensation for victims of forced sterilisation and 'Euthanasia' (Was ist typisches NS-Unrecht? Die verweigerte Entschädigung für Zwangssterilisierte und 'Euthanasie'-Geschädigte). In: Hamm M (ed) Unworthy of living-destroyed life. Forced sterilisation and Euthanasia (Lebensunwert-zerstörte Leben. Zwangssterilisation und Euthanasie). VAS-Verlag, Frankfurt/M., pp 198-211; Scheulen A (2005) The legal status and development of the 1934 sterilisation law (Zur Rechtslage und Rechtsentwicklung des Erbgesundheitsgesetzes 1934). In: Hamm M (ed) Unworthy of livingdestroyed life. Forced sterilisation and Euthanasia (Lebensunwertzerstörte Leben. Zwangssterilisation und Euthanasie). VAS-Verlag, Frankfurt/M., pp 212-219.

${ }^{36}$ Minutes of the 34th session of the Restitution Committee, Thursday 13 April 1961, p 16.

37 Plenary minutes 16/100, 100th session of the German Bundestag, Berlin, Thursday 24 May 2007.
} 
suspended at the time that came into force. The DGPPN supported calls to ban the Law at the time.

The Federal Indemnification Act of 1965, however, applies to this day, which means that mentally ill people who were forcibly sterilised or murdered have still not been explicitly acknowledged as victims of the Nazi regime or as victims of racial persecution. Lawmakers need to take action and change this before it is too late. Victims will not have received due recognition of their pain and suffering, which continues to this day, until the German government repeals this injustice as well.

The late 1960s and 1970s saw the first attempts to publish accounts of what happened in the field of psychiatry. Hans-Jörg Weitbrecht, Walter Ritter von Baeyer and Helmut Ehrhardt ${ }^{38}$ all wrote on the topic, yet all three presented psychiatry itself as a victim. ${ }^{39}$ A book commemorating the 130th anniversary of the German Association for Psychiatry and Psychotherapy in 1972 says that: "representatives of the psychiatric profession, despite their apparently far-reaching authority, never supported, endorsed or aided abuses such as 'euthanasia' ex officio. This is another reason to reject as objectively unfounded the repeated attempts to charge 'German psychiatry' with the misconduct or the crimes committed by individual psychiatrists at the time." 40

This was written by Helmut Ehrhardt, President of the DGPN from 1970 to 1972, who himself had been a member of the NSDAP and who had written reports endorsing forced sterilisation. As late as the hearings for the Federal Indemnification Act in the West German Bundestag in 1961, he said that the "actual content" ${ }^{41}$ of the Law for the Prevention of Hereditarily Diseased Offspring "was certainly not an invention of the Nazi regime, but rather something that in its essence reflected and still reflects

\footnotetext{
38 Ehrhardt HE (1965) Euthanasia and the "destruction of life unworthy of living" (Euthanasie und "Vernichtung lebensunwerten Lebens"). F. Enke, Stuttgart; von Baeyer W (1966) The vindication of Nazi ideology in medicine with particular regard to Euthanasia (Die Bestätigung der NS-Ideologie in der Medizin unter besonderer Berücksichtigung der Euthanasie). National socialism and the German university, Free University 1966 (Nationalsozialismus und die Deutsche Universität, Freie Universität 1966). de Gruyter, Berlin, pp 63-75; Weitbrecht H-J (1968) Psychiatry under national socialism (Psychiatrie in der Zeit des Nationalsozialismus). P. Hanstein, Bonn.

39 Cf. the analysis in Roelcke V (2007) Trauma or responsibility? Memories and historiographies of Nazi psychiatry in postwar Germany. In: Sarat A, Davidovich N, Alberstein M (eds) Trauma and memory. Reading, healing, and making law. Stanford University Press, Stanford, pp 225-242.

${ }^{40}$ Ehrhardt HE (1972) 130 years of the German Association for Psychiatry and Psychotherapy (130 Jahre Deutsche Gesellschaft für Psychiatrie und Nervenheilkunde). Wiesbaden, p 15.

${ }^{41}$ German Bundestag, minutes of the 34th session of the Restitution Committee, Thursday 13 April 1961, top of p 25.
}

current scientific conviction." ${ }^{42}$ This further mocks and degrades victims.

It is true that the association never officially endorsed killing patients. However, it is also true that it never officially condemned the practice either. There was never a single word of apology or reprimand.

And yet, with just a few exceptions, it appears that the overwhelming majority of German psychiatrists and members of our association, whether researchers, academics or practitioners, took part in planning, implementing and creating scientific legitimacy for sterilisation and murder. ${ }^{43}$

Research into German psychiatry under National Socialism only began in earnest in the early 1980 s. ${ }^{44}$ The main contributions from psychiatrists came from Klaus Dörner-who began in 1969 and produced a series of publications in the 1980s-Asmus Finzen and JoachimErnst Meyer. Among the historians were Gerhard Baader, Dirk Blasius and Hans-Walter Schmuhl. In 1983, Ernst Klee published his shocking book, "Euthanasia" in the Nazi State', which I read at the time in stunned disbelief. So, this was another book that deeply affected me.

During an anniversary congress held under the presidency of Uwe Henrik Peters in Cologne in 1992-when the name of the association was changed to DGPPN-the General Meeting passed a resolution in which the association reinforced "its feelings of revulsion and sorrow about the holocaust of the mentally ill, Jews and other victims of persecution." Back then, there was no mention of the institutional and personal guilt of psychiatrists and their representative organisation. However, it was a clear message that needed to be articulated.

During this year's congress, we are showing a revised and updated version of the In Memoriam exhibition, ${ }^{45}$ which drew large international audiences when it was first shown in 1999 at the World Congress of Psychiatry in Hamburg. A series of symposia accompanied the exhibition. The decision by the World Psychiatric Association to select Germany and the DGPPN as the hosts of the World Congress was a conciliatory gesture from the international psychiatric community - and it presented us with the solemn duty to begin commemorating the victims and to make

\footnotetext{
$\overline{42}$ Ibid, bottom of page.

${ }^{43}$ Cf. Meyer-Lindenberg J (1991) The Holocaust and German Psychiatry. Br J Psychiatry 159:7-12, especially p 9; Roelcke V (2010) Psychiatry under national socialism. Historical findings, implications for current ethical debates (Psychiatrie im Nationalsozialismus. Historische Kenntnisse, Implikationen für aktuelle ethische Debatten). Nervenarzt 81:1317-1325.

${ }^{44}$ For more on the history of the psychiatric profession coming to terms with its past cf. Roelcke, Trauma or responsibility (note 39).

45 von Cranach M, Schneider F (2010) In Memoriam. Remembrance and responsibility. Exhibition catalogue. Springer, Berlin.
} 
serious efforts to come to terms with the history of our profession.

Over the past 2 years, the DGPPN has held a series of in-depth discussions about how to deal with its own history. These talks were not controversial; they were conducted by mutual agreement. As a result of the talks, we amended the DGPPN's Articles of Association exactly 1 year ago. The first paragraph now reads:

"The DGPPN recognises that it bears a special responsibility to protect the dignity and rights of people suffering from mental illness. This responsibility is the result of its predecessors' involvement in the crimes of National Socialism, in killing and forcibly sterilising hundreds of thousands of patients."

Another outcome of the discussions was that, early this year, the DGPPN Executive Committee established an international commission to address the actions of the predecessor associations that existed during the "Third Reich." The commission is made up of four renowned historians of medicine and science: the chairman, Professor Roelcke from Gießen, Professor Sachse from Vienna, Professor Schmiedebach from Hamburg and Professor Weindling from Oxford. The commission makes its decisions independently of the DGPPN, as we realise how important complete transparency is in this type of work. We are extremely grateful to the members of the commission for helping us in our efforts to come to terms with our past.

The commission is overseeing the DGPPN-initiated and financed research projects involving Professor Schmuhl and Professor Zalashik. They aim to shed light on the extent to which the DGPPN's predecessor organisations and their representatives were involved in the "euthanasia" programme, in forced sterilisations of mentally ill patients and in other crimes between 1933 and 1945.

The final report is due to be presented in just under 2 years, after which a second phase will begin the equally long-overdue task of addressing the post-war period. It will explore the consequences of the terrible crimes perpetrated under the Nazis, uncover who was involved, and reveal what lessons were learned and when. This will replace the speculation surrounding this period with solid facts.

"Mentally dead," "human ballast," "life unworthy of living" - these are not easy words to say. They are deeply upsetting and disturbing - and, in the light of the fact that psychiatrists were actively involved in "Gleichschaltung," forced sterilisation and murder, they fill us with shame, anger and the greatest sorrow.
Our shame and regret are also rooted in the fact that it has taken this association, of which I am President today, 70 years to make a systematic effort to come to terms with its past and the history of its predecessors under National Socialism, and-irrespective of the historical facts that may come to light - to ask for forgiveness from the victims of forced migration, forced sterilisation, human experiments and murder.

In the name of the German Association for Psychiatry and Psychotherapy, I ask you, the victims and relatives of the victims, for forgiveness for the pain and injustice you suffered in the name of German psychiatry and at the hands of German psychiatrists under National Socialism, and for the silence, trivialisation and denial that for far too long characterised psychiatry in post-war Germany.

Many of the victims, even those who were not killed, and their families are no longer with us today. For them, this request comes too late. But perhaps it is not too late for the survivors and for the victims' descendants-some of whom are with us here today-for mentally ill people everywhere and for today's psychiatrists and the DGPPN itself.

We cannot undo pain, injustice and death. But we can learn lessons, and we have learned a great many-in the psychiatry profession, in medicine as a whole and in politics and society. And we can commemorate the victims by coming together to advocate humane, patient-oriented psychiatry and by working together to fight the stigmatisation and marginalisation of mentally ill people.

As psychiatrists, we must not pass value judgements on people. We teach, research, treat, support and cure. When we speak of the inviolability of human dignity, we mean the dignity of each and every individual, and no law or research objective must ever cause us to disregard this again.

We have learned important lessons from our failures. This offers hope for current debates on medical ethics, which, given their focus on topics such as preimplantation genetic diagnosis and assisted suicide, risk descending all too quickly into questions of the "value" of a human life. These discussions will always be murky, but I believe that my goal and the goal of the DGPPN as a whole is perfectly clear-we must ensure we provide humane medical care, contribute to a more benign future and respect the dignity of every single individual.

Ladies and gentlemen, thank you for your attention.

This supplement was not sponsored by outside commercial interests. It was funded by the German Association for Psychiatry and Psychotherapy (DGPPN). 